Department of Preventive and Social Medicine, University of Otago, Dunedin New Zealand

Correspondence to: D C G Skegg david.skegg@otago.ac.nz Cite this as: BMJ 2021;374:n1794 http://dx.doi.org/10.1136/bmj.n1794 Published: 15 July 2021

\title{
Defining covid-19 elimination
}

\section{Elimination is achievable and should not be confused with eradication}

\section{David CG Skegg, Philip C Hill}

Speaking about progress towards ending the covid-19 epidemic in the United States, Anthony Fauci said: "We will end the epidemic phase, and we will likely get somewhere between control and elimination, more likely closer to control." ${ }^{1}$ Now authorities in England are abandoning most efforts to control, let alone eliminate, the infection. ${ }^{2}$ Throughout the pandemic, the word "elimination" has been used in different senses. Many confuse elimination with eradication, which normally means permanent reduction to zero of the worldwide incidence of an infection-as was achieved for smallpox. ${ }^{3}$ This confusion helps to make the idea of eliminating covid-19 seem impossible and not worth pursuing. Elimination is variously defined but stops short of permanent eradication of infection.

Countries pursuing an elimination strategy have experienced less disruption and economic damage than those that have focused on mitigation to protect health services..$^{-6} \mathrm{~A}$ comparison of five member countries of the Organisation for Economic Cooperation and Development that aimed for elimination with 32 others that opted for mitigation indicated that elimination creates the best outcomes for health, the economy, and civil liberties. ${ }^{4}$ The authors defined elimination as "maximum action to control SARS-CoV-2 and stop community transmission as quickly as possible.” This is an action oriented definition, which acknowledges that some community transmission of the virus will occur after importation, though steps will be taken to extinguish it. A similar approach was advocated by the head of the New Zealand health service, who declared that elimination focuses on zero tolerance towards new cases, rather than a goal of no new cases. ${ }^{7}$

\section{Although elimination of an infection is often} interpreted as the reduction of incidence to zero in a defined geographical area, ${ }^{3}$ a widely used reference book of epidemiological terms defines elimination as reduction of case transmission to a predetermined very low level. ${ }^{8}$ The World Health Organization has defined elimination of tuberculosis, for example, as a reduction in prevalence to below one case per million population. ${ }^{8} \mathrm{~A}$ WHO definition for the elimination of measles in a country allows for importation of cases, as long as endemic transmission of the measles virus strain does not continue for more than 12 months. ${ }^{9}$ So far, there is no internationally agreed definition for the elimination of SARS-CoV-2.

Several countries, mainly in the Asia-Pacific region, have adopted an elimination strategy for controlling SARS-CoV-2. ${ }^{10}$ These countries include about a quarter of the world's population. They have experienced relatively small burdens of covid-19 disease and relatively few deaths, but none has had "zero covid" for a prolonged period. Even with border restrictions and strict quarantine, incursions of the virus occur from time to time, leading to clusters of infections and occasional large outbreaks. In the Australian state of Victoria, for example, a resurgence of covid-19 last year peaked at over 700 cases a day, before being extinguished after three months. ${ }^{11}$ Despite such setbacks, Australia and New Zealand remain healthy economies with largely normal community life, apart from temporary border restrictions. Both are developing plans for a phased reopening of borders.

The likely consequences of not aiming for elimination have been detailed by leading researchers Christopher Murray and Peter Piot, who predicted that SARS-CoV-2 may become a recurrent seasonal infection in the US, requiring health system change and "profound cultural adjustment for the life of high risk individuals in the winter months." ${ }^{12}$ Moves in some countries, including England, to relax public health and social measures for controlling the virus in partially vaccinated populations might drive the emergence of new variants that are resistant to current vaccines. If such variants caused severe disease, the case for an elimination strategy would become compelling.

\section{Ambition, leadership}

The emergence of more transmissible variants presents challenges for controlling SARS-CoV-2 by conventional public health measures. Yet stamping out most covid-19 should be more feasible with the advent of highly effective vaccines-if current problems of global scarcity and inequitable distribution can be resolved. The effects of high vaccination coverage in Israel show what can be achieved ${ }^{13}$ and that vaccination must be combined with other measures including widespread testing, isolation of cases, contact tracing, and social measures such as mask wearing. ${ }^{11}$ This requires political leaders capable of convincing citizens of the huge benefits of stopping community transmission. That will be difficult in places where citizens are already wearied by the faltering control efforts of the past year. An elimination strategy might be especially important in countries lightly touched by the virus so far, although the costs of stringent control measures might be daunting for low income countries.

An unduly strict interpretation of elimination may discourage countries from adopting this ambitious approach. Instead of being equated with "zero covid," elimination of SARS-CoV-2 in a population could be defined as "achievement of a situation in which outbreaks of covid-19 are extinguished eventually, with no continuing widespread transmission.” 
The Independent Panel for Pandemic Preparedness and Response has urged WHO to develop a road map to guide efforts towards ending the covid-19 pandemic within countries and globally. ${ }^{14}$ In doing so, WHO should set out and promote a realistic definition of elimination in the context of SARS-CoV-2. This would encourage ambition, rather than defeatism, in confronting the coronavirus causing such havoc around the globe.

\section{Provenance and peer review: Not commissioned, peer reviewed}

Competing interests: We have read and understood BMJ policy on declaration of interests and declare that DS is the chair and PH is a member of New Zealand's Strategic Covid-19 Public Health Advisory Group. DS is also a member of the oversight panel for the Covid-19 Scenarios Project of the International Science Council.

1 Achenbach J. Is it now reasonable to discuss the end of the pandemic? Yes, but with caveats. Washington Post2021; May 13. https://www.washingtonpost.com/health/when-will-the-pandemicend/2021/05/13/1fcee324-b116-11eb-ab43-bebddc5aOf65_story.html

2 Wise J. Covid-19: Ending all restrictions in England on 19 July “dangerous and premature," say experts. BMJ2021;374:n1751. doi: 10.1136/bmj.n1751 pmid: 34244245

3 Dowdle WR. The principles of disease elimination and eradication. Bull World Health Organ 1998;76(Suppl 2):22-5.pmid: 10063669

4 Oliu-Barton M, Pradelski BSR, Aghion P, etal. SARS-CoV-2 elimination, not mitigation, creates best outcomes for health, the economy, and civil liberties. Lancet 2021;397:2234-6. doi: 10.1016/S0140-6736(21)00978-8 pmid: 33932328

5 Charumilind S, Greenberg E, Lamb J, Singhal S. Covid-19: saving thousands of lives and trillions in livelihoods. McKinsey Insights2020 Aug 17. https://www.mckinsey.com/industries/healthcaresystems-and-services/our-insights/covid-19-saving-thousands-of-lives-and-trillions-in-livelihoods

6 Philippe C, Marques N. The zero covid strategy protects people and economies more effectively. Institut Economique Molinari, Paris-Bruxelles; 3 Apr 2021. https://www.institutmolinari.org/2021/04/03/the-zero-covid-strategy-protects-people-and-economies-more-effectively/

7 Morrah M. Coronavirus: Dr Ashley Bloomfield defines elimination after Prime Minister Jacinda Ardern's comments. Newshub 2020; published online April 28. https://www.newshub.co.nz/home/politics/2020/04/coronavirus-dr-ashley-bloomfield-defines-elimination-afterprime-minister-jacinda-ardern-s-comments.html

8 Porta M, ed. A dictionary of epidemiology. 6th ed. Oxford University Press, 2014.doi: 10.1093/acref/9780199976720.001.0001.

9 World Health Organization. Guidelines on verification of measles and rubella elimination in the Western Pacific Region. 2nd ed. WHO Regional Office for the Western Pacific, 2019. https://iris.wpro.who.int/handle/10665.1/14481

10 The Lancet Infectious Diseases. The covid-19 exit strategy - why we need to aim low. Lancet Infect Dis 2021;21:297. doi: 10.1016/S1473-3099(21)00080-3 pmid: 33581748

11 Baker MG, Wilson N, Blakely T. Elimination could be the optimal response strategy for covid-19 and other emerging pandemic diseases. BMJ2020;371:m4907. doi: 10.1136/bmj.m4907 pmid: 33561814

12 Murray CJL, Piot P. The potential future of the covid-19 pandemic: will SARS-CoV-2 become a recurrent seasonal infection?JAMA 2021;325:1249-50 doi: 10.1001/jama.2021.2828 pmid: 33656519

13 Rossman H, Shilo S, Meir T, Gorfine M, Shalit U, Segal E. Covid-19 dynamics after a national immunization program in Israel. Nat Med 2021;27:1055-61. doi: 10.1038/s41591-021-01337-2 pmid: 33875890

14 Independent Panel for Pandemic Preparedness and Response. Covid-19: Make it the last pandemic 2021. https://theindependentpanel.org/wp-content/uploads/2021/05/COVID-19-Make-it-theLast-Pandemic_final.pdf

This article is made freely available for use in accordance with BMJ's website terms and conditions for the duration of the covid-19 pandemic or until otherwise determined by BMJ. You may use, download and print the article for any lawful, non-commercial purpose (including text and data mining) provided that all copyright notices and trade marks are retained. 